\title{
Influence of Basal Insulin and Glucagon Secretion on Potassium and Sodium Metabolism
}

\author{
STUDIES WITH SOMATOSTATIN IN NORMAL DOGS AND IN NORMAL
} AND DIABETIC HUMAN BEINGS

\author{
Ralph A. DeFronzo, Robert S. Sherwin, Mark Dillingham, \\ Rosa Hendler, William V. Tamborlane, and Philip Felig, \\ the Department of Internal Medicine, Yale University School \\ of Medicine, New Haven, Connecticut 06510
}

\begin{abstract}
A B S T RACT To examine the role of basal insulin and glucagon secretion in potassium and sodium homeostasis, somatostatin, a potent inhibitor of insulin and glucagon secretion, was infused for $5 \mathrm{~h}$ into healthy human subjects, maturity-onset diabetes, juvenile-onset diabetics, and normal dogs. Infusion of somatostatin resulted in an increase in serum potassium (0.5-0.6 meq/liter) in normal subjects and maturity-onset diabetics, but not in juvenile-onset diabetics despite equivalent reductions in plasma glucagon in all three groups. A similar rise in serum potassium was observed in normal conscious dogs given somatostatin and was reversed by insulin replacement. Urinary excretion of potassium was unaffected by somatostatin.
\end{abstract}

In dogs given intravenous potassium chloride in doses $(0.375 \mathrm{meq} / \mathrm{kg}$ per $\mathrm{h})$ which do not alter basal insulin levels, the rise in serum potassium $(0.6 \mathrm{meq} /$ liter in controls) increased $100 \%$ when somatostatin was administered together with the $\mathrm{KCl}$ infusion. Addition of replacement doses of insulin to the somatostatin infusion resulted in increments in serum potassium which were comparable to infusion of $\mathrm{KCl}$ alone. Urinary potassium excretion rose after $\mathrm{KCl}$ administration and was unchanged by the addition of somatostatin.

Serum sodium concentration was unaffected by somatostatin administration in both the human and dog studies. However, urinary sodium excretion displayed a biphasic response falling by $20-60 \%$ within the first $2 \mathrm{~h}$ of somatostatin administration and then

Dr. Felig is an Established Investigator of the American Diabetes Association.

Received for publication 24 June 1977 and in revised form 10 October 1977. rising to values $50-80 \%$ above basal levels at $3-4 \mathrm{~h}$. Inulin and $p$-aminohippurate clearances were unaffected by somatostatin.

It is concluded that $(a)$ potassium homeostasis is influenced by basal insulin levels in the absence of which serum potassium concentration rises and potassium tolerance declines; $(b)$ this effect of insulin is mediated via extrarenal mechanisms of potassium disposal; (c) somatostatin has a biphasic effect on urinary sodium secretion, the mechanism of which remains to be established.

\section{INTRODUCTION}

The regulation of body potassium balance is considered to be primarily determined by the adrenal cortex and the kidneys $(1,2)$. The rate of urinary excretion of potassium is influenced by the secretion of aldosterone (3) and the pericapillary potassium concentration bathing the distal and collecting tubules (4). With respect to circulating levels of potassium, it has also long been recognized that physiologic increases in plasma insulin will lower the serum potassium concentration by stimulating cellular uptake of this ion in muscle (5) and liver tissue (6). In addition, the disposal of large exogenous loads of potassium, which are capable of stimulating insulin secretion in normal subjects (7-9), is reduced in the diabetic state (9-11). However, whether or not basal levels of insulin (as observed in the postabsorptive state) influence endogenous potassium homeostasis or the disposal of small exogenous loads of potassium has not been established. Furthermore, although increases in insulin have been shown to have an antinatriuretic effect $(12,13)$ and since a natriuretic 
action has been ascribed to hyperglucagonemia (14), whether or not basal levels of these hormones influence urinary sodium excretion has not been determined. In the present study the role of basal insulin and glucagon secretion in potassium and sodium homeostasis was examined by administering somatostatin, a potent inhibitor of insulin and glucagon secretion (15).

\section{METHODS}

\section{Human studies}

Studies were undertaken in three groups of subjects: (a) nine healthy nonobese volunteers, 20-38 yr of age; (b) six maturity-onset diabetics, 41-60 yr of age, with fasting plasma glucose levels of $121-285 \mathrm{mg} / 100 \mathrm{ml}$ who were being managed with diet alone; and $(c)$ three juvenileonset diabetics, (insulin-dependent) 31-38 yr of age, with fasting plasma glucose levels of $225-285 \mathrm{mg} / \mathrm{dl}$, who were receiving 50-62 $\mathrm{U}$ of intermediate acting insulin per day. Subjects did not receive any medications other than the insulin given to the juvenile-onset diabetics. All subjects had been on a weight-maintaining diet containing at least $200 \mathrm{~g}$ of carbohydrate for at least 3 days before study. They were informed of the nature, purpose, and possible risks of the study before obtaining their written, voluntary consent to participate.

All studies were begun at 8 a.m. after a 12 - to 15 -h overnight fast. Insulin was withheld from the juvenileonset diabetics on the morning of study. A polyethylene catheter was placed in an antecubital vein for infusion of somatostatin and in the contralateral vein for blood sampling. After a 60 -min control period, linear somatostatin. (kindly provided by Dr. Roger Guillemin and Dr. Jean Rivier of the Salk Institute, San Diego, Calif.) was prepared for infusion as described previously (16) and administered in a $9-\mu \mathrm{g} / \mathrm{min}$ dose for $5 \mathrm{~h}$ by means of a peristaltic pump (Extracorporeal Medical Specialities, Inc., King of Prussia, Pa.). In six of the normal subjects a water diuresis (15 $\mathrm{ml} / \mathrm{kg}$ ) was initiated before the infusion of somatostatin and the volume of each voided urine was quantitatively replaced with deionized water to ensure voiding every $45-60 \mathrm{~min}$.

\section{Studies in dogs}

Studies were undertaken in normal dogs in which the effects of somatostatin on basal potassium and sodium metabolism were determined and the response to potassium chloride infusion was examined.

\section{BASAL POTASSIUM METABOLISM}

10 normal, conscious male dogs ranging in weight from 17 to $31 \mathrm{~kg}$ were studied at $8 \mathrm{a} . \mathrm{m}$. after a 15 -h fast. All dogs were maintained on standard Purina Dog Chow (Ralston Purina Co., St. Louis, Mo.) for at least 7 days before study. On the morning of study they were placed in a total body sling and allowed to rest comfortably on their side. Polyethylene catheters were inserted into a forelimb vein for infusion of somatostatin (seven dogs) and into a hindlimb vein for blood sampling. Three dogs, serving as controls, received a saline infusion only. After an initial adjustment period of $30 \mathrm{~min}$, three control blood samples were drawn at 30-min intervals. Seven dogs then received an infusion of cyclic somatostatin (Bachem, Inc., Marina Del Rey, Calif.) at a rate of $0.2 \mu \mathrm{g} / \mathrm{kg}$ per min for $5 \mathrm{~h}$. During the final $2 \mathrm{~h}$ of the study, insulin in basal replacement amounts $(0.15 \mathrm{mU} / \mathrm{kg}$ per $\mathrm{min})$ was added to the somatostatin infusion.

\section{RESPONSE TO POTASSIUM CHLORIDE}

Eight dogs (three female and five male) ranging in weight from 18 to $30 \mathrm{~kg}$ were divided into two groups of four. The first group of dogs (group I) was studied in the awake state and the second group (group II) was anesthetized before study. All studies were begun at 8 a.m. after a 14 -h fast.

Group I. On the morning of the study all dogs were placed in a total body sling and allowed to rest comfortably on their side. Polyethylene catheters were inserted into a forelimb vein for infusion of test substances and into a hindlimb vein for blood sampling. After an initial equilibration period of $30 \mathrm{~min}$, three control blood samples were drawn at 15-min intervals. Each dog then received an infusion of (a) potassium chloride $(0.375 \mathrm{meq} / \mathrm{kg}$ per $\mathrm{h})$ alone; (b) cyclic somatostatin $(0.2 \mu \mathrm{g} / \mathrm{kg}$ per $\mathrm{min})$ in combination with potassium chloride; and $(c)$ insulin $(0.2 \mathrm{mU} / \mathrm{kg}$ per min) in combination with potassium chloride and somatostatin. In each study potassium chloride was administered for $4 \mathrm{~h}$. The infusion of somatostatin or somatostatin plus insulin was initiated $30 \mathrm{~min}$ preceding the infusion of potassium chloride and then continued throughout the 4-h infusion of $\mathrm{KCl}$. Each dog was studied with each infusion protocol at 7- to 10-day intervals. The order of study was randomized.

Group II. Dogs were anesthetized with intravenous pentobarbital $(88 \mathrm{mg} / \mathrm{kg})$, immediately after which an endotracheal tube was inserted and attached to a variable speed Harvard respirator (Harvard Apparatus Co., Inc., Millis, Mass.). Each dog was ventilated at 12 breaths/min with a tidal volume of $15 \mathrm{ml} / \mathrm{kg}$. Additional pentobarbital was given as necessary to maintain the $\operatorname{dog}$ in a lightly anesthetized state. Polyethylene catheters were then inserted into a forelimb vein for infusion of test substances and into a hindlimb vein for blood sampling. A urinary bladder catheter was inserted for collection of urine samples.

Priming doses of inulin $(40 \mathrm{mg} / \mathrm{kg}$ body wt) and $p$-aminohippurate $(\mathrm{PAH})^{1}(12 \mathrm{mg} / \mathrm{kg}$ body wt) were given intravenously and sustaining infusions of inulin and $\mathrm{PAH}$ in $0.9 \%$ sodium chloride were administered at a rate of 0.5 $\mathrm{ml} / \mathrm{min}$ throughout the study to maintain plasma levels of 20 and $2.0 \mathrm{mg} / \mathrm{ml}$, respectively. Immediately after the insertion of the intravenous catheters $500 \mathrm{ml}$ of normal saline was infused over $30 \mathrm{~min}$ to ensure an adequate urine output. After a 60-min equilibration period, two 30-min control urine samples were collected. The dogs then received either potassium chloride $(0.375 \mathrm{meg} / \mathrm{kg}$ per $\mathrm{h})$ alone for $4 \mathrm{~h}$, or cyclic somatostatin $(0.2 \mu \mathrm{g} / \mathrm{kg}$ per min) and potassium chloride $(0.375 \mathrm{meq} / \mathrm{kg}$ per $\mathrm{h})$. Blood and urine samples were collected at 30 -min intervals throughout the study. The volume of blood withdrawn was replaced quantitatively with normal saline to avoid volume depletion. Each dog received both infusion protocols at 7- to 10-day intervals. The order of studies was randomized.

\section{Analytical methods}

Serum and urine potassium and sodium concentrations were determined by flame photometry using lithium as an

\footnotetext{
${ }^{1}$ Abbreviation used in this paper: $\mathrm{PAH}, p$-aminohippurate.
} 
internal standard (Flame Photometer 143, Instrumentation Laboratory, Inc., Lexington, Mass.) Plasma and urine PAH concentrations were measured by the method of Smith (17) using a Gilford spectrophotometer at $540 \mathrm{~nm}$ (Gilford Instrument Laboratories Inc., Oberlin, Ohio). Inulin concentrations in plasma and urine were quantitated by the method of Walser et al. (18) adapted to the AutoAnalyzer (Technicon Instruments Corp., Tarrytown, N. Y.) by Fuhr et al. (19). Serum and urine creatinine was measured by the method of Folin and Wu (20) adapted to the AutoAnalyzer. Plasma insulin was determined by radioimmunoassay with the use of talc to separate free from bound insulin (21). Plasma glucagon was measured by radioimmunoassay employing the $30-\mathrm{K}$ antibody of Unger (22). Plasma was treated with aprotinin (Trasylol) to prevent degradation of the glucagon. Plasma glucose concentration was determined by the glucose oxidase method employing a Beckman glucose analyzer (Beckman Instruments, Inc., Science Essentials Co., Mountainside, N. J.).

\section{Data analysis}

Data are presented as the mean \pm standard error of the means. Urinary electrolyte excretion, clearance values, and fractional excretion of electrolytes were calculated using standard formulas. The paired and unpaired $t$ tests were employed in the statistical analyses (23).

\section{RESULTS}

\section{Human studies}

In Fig. 1, the effects of prolonged infusion of somatostatin on plasma glucose, insulin, and glucagon are shown for the healthy controls, maturity-onset diabetics, and juvenile-onset diabetics. As expected $(15,24)$, in the normal subjects and maturity-onset diabetics, somatostatin resulted in a prompt and sustained decline in plasma insulin of 56 and $63 \%$, respectively. In all groups, plasma glucagon fell by $40-60 \%$. Plasma glucose in the normal subjects and maturity-onset diabetics showed the previously described $(15,24)$ biphasic response characterized by an initial decline in blood glucose, followed by a subsequent rise to values $8-31 \mathrm{mg} / 100 \mathrm{ml}$ above base line. In the juvenile-onset diabetics, blood glucose showed an initial decline and then plateaued at $4-5 \mathrm{~h}$.

Serum potassium concentration in the basal state was similar in the controls $(4.02 \pm 0.08 \mathrm{meq} / \mathrm{liter})$, the maturity-onset diabetics $(3.88 \pm 0.09 \mathrm{meq} / \mathrm{liter})$ and the juvenile-onset diabetics $(4.07 \pm 0.15 \mathrm{meq} / \mathrm{liter})$. In Fig. 2 , the changes in serum potassium in response to infusion of somatostatin are shown. In the normal controls and maturity-onset diabetics serum potassium rose significantly above base-line values by $30 \mathrm{~min}$ $(P<0.01)$ and reached peak levels at $240 \mathrm{~min}$. The maximum increase in serum potassium concentration was $0.57 \pm 0.16 \mathrm{meq} / \mathrm{liter}$ in the normal group and 0.56 $\pm 0.12 \mathrm{meq} / \mathrm{liter}$ in the maturity-onset diabetics. In marked contrast, no significant change in serum
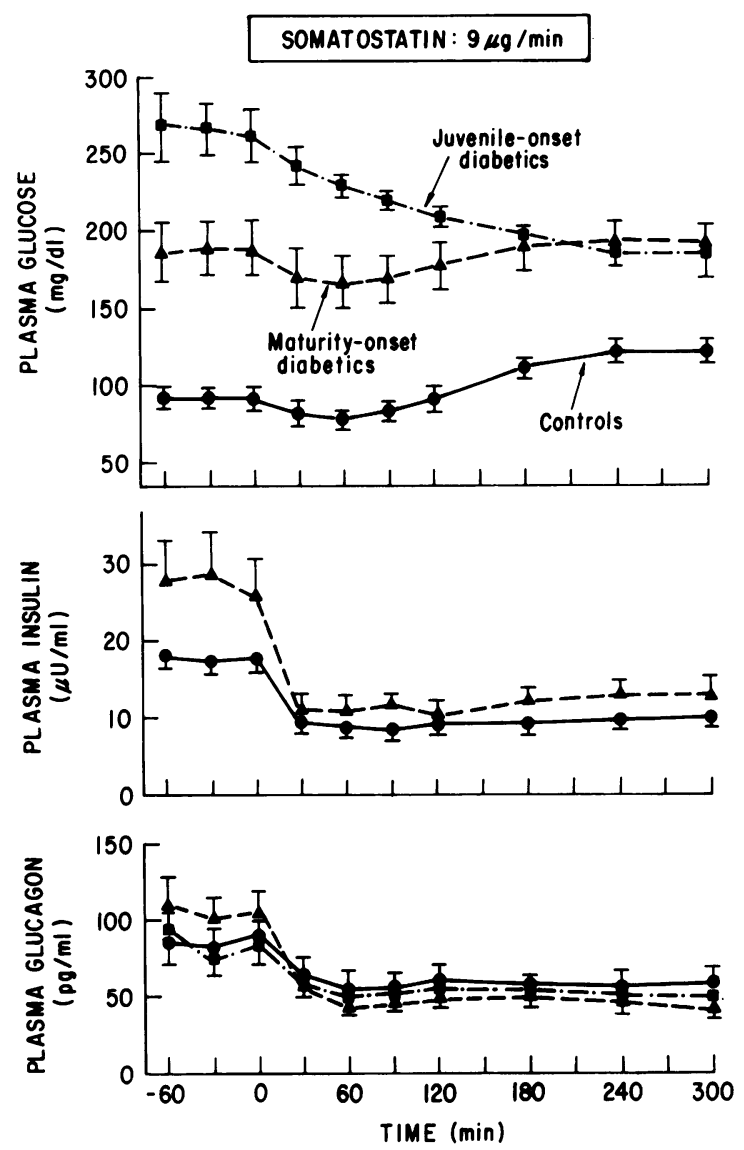

FIGURE 1 The effect of somatostatin infusion on plasma glucose, insulin, and glucagon concentrations in normal controls $(\boldsymbol{O})$, maturity-onset diabetics $(\boldsymbol{\Delta})$, and juvenile-onset diabetics (घ). Plasma insulin was not measured in the juvenile-onset diabetics because of the presence of circulating insulin antibodies. Each point represents the mean \pm SEM.

potassium occurred in the juvenile-onset diabetics (Fig. 2).

Serum sodium concentration $(139.6 \pm 0.6 \mathrm{meq} / \mathrm{liter}$ in the controls, $136.5 \pm 0.6 \mathrm{meq} / \mathrm{liter}$ in the maturity-onset diabetics, and $137.5 \pm 0.9 \mathrm{meq} / \mathrm{liter}$ in the juvenileonset diabetics) was unaffected by the somatostatin infusion in any of the groups.

In Figs. 3 and 4 the effects of somatostatin on urinary excretion of potassium and sodium in the normal subjects are shown. Urinary potassium excretion was unchanged during somatostatin administration. In contrast, urinary sodium excretion fell by $26 \%$ during the first $120 \mathrm{~min}$ of the somatostatin infusion $(P<0.01)$, and then rose to values $59 \%$ above basal levels $(P<0.01)$ by the end of the infusion. Creatinine clearance $(121 \pm 6 \mathrm{ml} / \mathrm{min}$ in the basal state) was unchanged during the somatostatin infusion. The urine was free of glucose throughout the somatostatin infusion. 


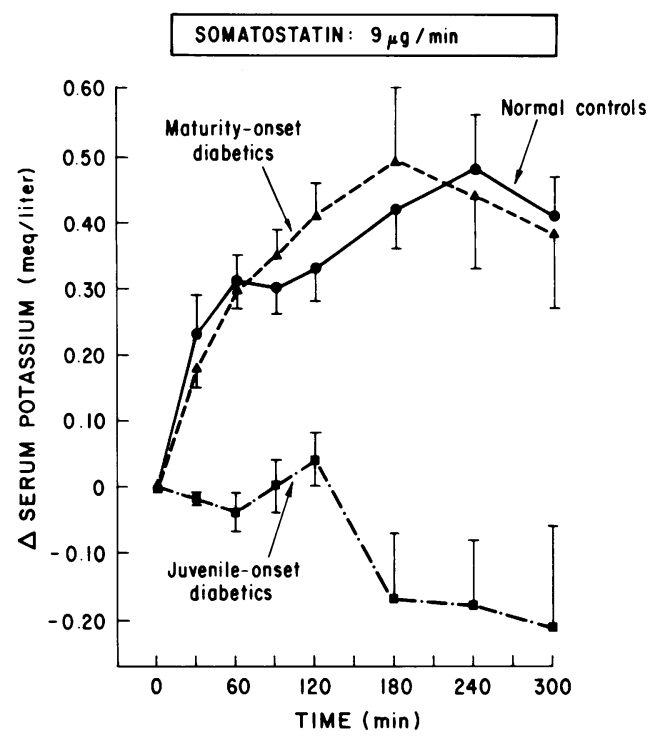

FIGURE 2 The effect of somatostatin infusion on the change in serum potassium concentration in normal controls (0), maturity-onset diabetics $(\mathbf{\Delta})$, and juvenile-onset diabetics (ם).

\section{Studies in dogs}

Basal potassium metabolism (Fig. 5). After somatostatin the plasma insulin concentration declined from $20 \pm 1$ to $11 \pm 1 \mu \mathrm{U} / \mathrm{ml}(P<0.01)$ by $15 \mathrm{~min}$ and remained suppressed. Serum potassium concentration increased from $4.18 \pm 0.07$ to $4.41 \pm 0.07 \mathrm{meq} / \mathrm{liter}$ $(P<0.01)$ by $30 \mathrm{~min}$ and continued to rise reaching

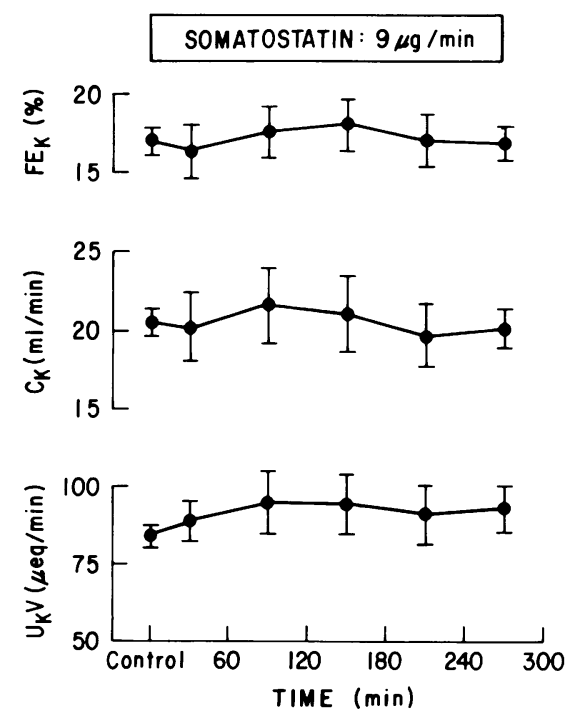

FIGURE 3 The effect of somatostatin infusion on urinary potassium excretion $\left(U_{K} V\right)$, potassium clearance $\left(C_{K}\right)$, and fractional excretion of potassium $\left(\mathrm{FE}_{\mathrm{K}}\right)$ in normal control subjects.
$4.70 \pm 0.11 \mathrm{meq} / \mathrm{liter}(P<0.001)$ by $180 \mathrm{~min}$. The maximum increase in plasma potassium concentration was $0.63 \pm 0.07 \mathrm{meq} / \mathrm{liter}$. Venous $\mathrm{pH}(7.36 \pm 0.02$ vs. 7.37 $\pm 0.02)$ and bicarbonate $(24 \pm 1.6$ vs. $25 \pm 1.4 \mathrm{meq} / \mathrm{liter})$ were unchanged after $5 \mathrm{~h}$. Addition of replacement doses of insulin to the somatostatin infusion resulted in a rise in plasma insulin to basal levels and a fall in plasma potassium concentration to base-line values (Fig. 5). In the three dogs given saline no change in plasma potassium concentration was observed during the 5-h infusion.

Response to potassium chloride infusion. Since the responses in plasma glucose, insulin, and serum potassium were identical in the awake and anesthetized dogs, the results of the two groups have been combined. Basal glucose and insulin concentrations in the eight dogs were $96 \pm 6 \mathrm{mg} / \mathrm{dl}$ and $25 \pm 4 \mu \mathrm{U} / \mathrm{ml}$, respectively. Plasma glucagon concentration in the four awake dogs was $38 \pm 5 \mathrm{pg} / \mathrm{ml}$ and in the four anesthetized dogs was $198 \pm 68 \mathrm{pg} / \mathrm{ml}$. After the potassium chloride infusion no significant changes in plasma glucose, insulin, or glucagon was observed. Addition of somatostatin to the $\mathrm{KCl}$ infusion resulted
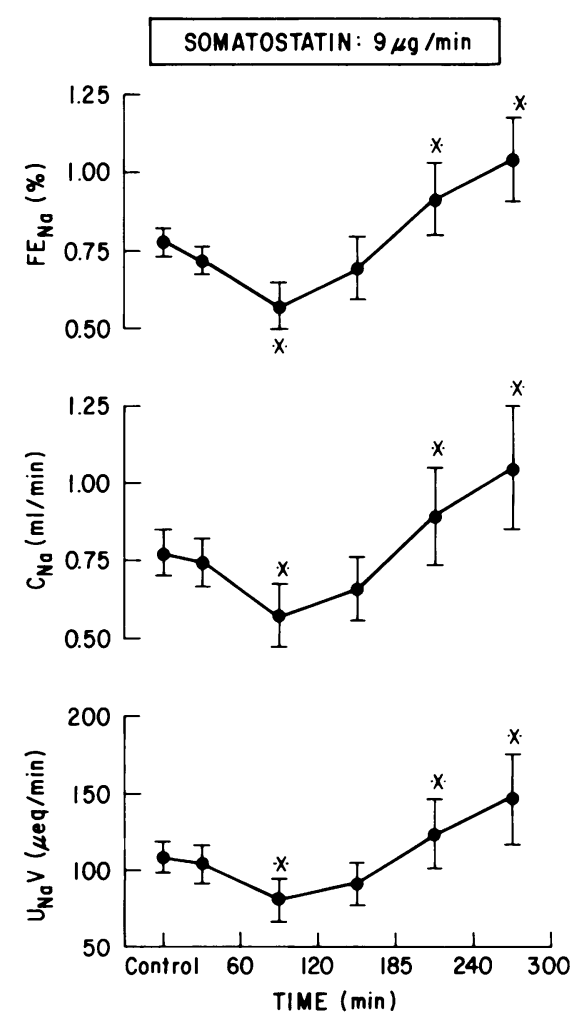

FIGURE 4 The effect of somatostatin infusion on urinary sodium excretion $\left(\mathrm{U}_{\mathrm{Na}} \mathrm{V}\right)$, sodium clearance $\left(\mathrm{C}_{\mathrm{Na}}\right)$ and fractional excretion of sodium $\left(\mathrm{FE}_{\mathrm{Na}}\right)$ in normal control subjects. An asterisk represents a $P$ value $<0.01$ when compared to basal excretion (paired $t$ test). 


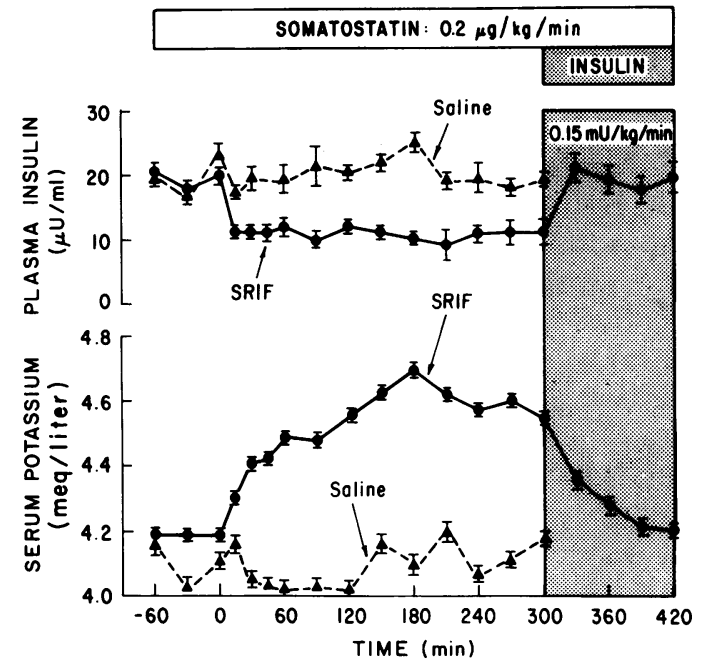

FIgure 5 The effect of somatostatin (SRIF) (O) or saline (A) infusion on plasma insulin and serum potassium concentration in conscious dogs. The effect of basal insulin replacement is shown by the shaded area.

in a fall in plasma insulin which was prevented by the combined infusion of $\mathrm{KCl}$, somatostatin, and insulin (Fig. 6). Plasma glucagon fell by $46 \pm 8 \%(P<0.05)$ in the awake dogs during the combined somatostatin$\mathrm{KCl}$ infusion but failed to decline or rose slightly in the anesthetized dogs receiving the combined somatostatin- $\mathrm{KCl}$ infusion.

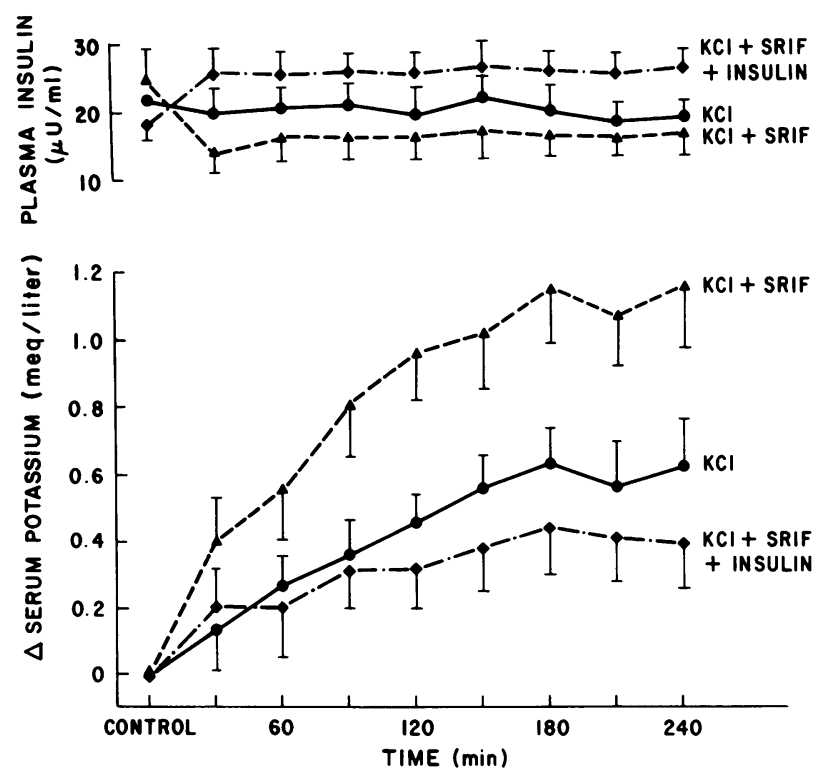

Figure 6 The effect of potassium chloride $(\mathrm{KCl})$ infusion alone $(\bullet), \mathrm{KCl}$ plus somatostatin $(\mathrm{SRIF})$ infusion $(\boldsymbol{\Delta})$, and $\mathrm{KCl}$ plus SRIF plus insulin $(\bullet)$ on plasma insulin concentration and the change in serum potassium concentration in dogs.
Before $\mathrm{KCl}$ infusion, basal levels of serum potassium were similar in all studies $(\mathrm{KCl}$ alone: $4.16 \pm 0.16$ meq/liter; $\mathrm{KCl}$ plus somatostatin: 3.92 $\pm 0.20 \mathrm{meq} / \mathrm{liter} ; \mathrm{KCl}$ plus somatostatin plus insulin: $4.10 \pm 0.26 \mathrm{me} / \mathrm{liter})$. The changes in serum potassium concentration after $\mathrm{KCl}$ infusion are shown in Fig. 6 . The maximum rise in serum potassium after infusion of $\mathrm{KCl}$ alone was $0.63 \pm 0.15 \mathrm{meq} / \mathrm{liter}$. Addition of somatostatin approximately doubled the rise in serum potassium to $1.16 \pm 0.20 \mathrm{meq} / \mathrm{liter}(P<0.01)$ without change in venous $\mathrm{pH}(7.35 \pm 0.02$ vs. $7.36 \pm 0.02)$ or bicarbonate $(21 \pm 1.5$ vs. $22 \pm 1.6 \mathrm{meq} / \mathrm{liter})$. When insulin was added to the somatostatin infusion, the rise in serum potassium $(0.40 \pm 0.15 \mathrm{meq} / \mathrm{liter})$ was equivalent to that observed with $\mathrm{KCl}$ alone.

In the basal state, inulin clearance was $69 \pm 6 \mathrm{ml} / \mathrm{min}$ and $\mathrm{PAH}$ clearance was $212 \pm 16 \mathrm{ml} / \mathrm{min}$. Neither parameter was altered by $\mathrm{KCl}$ infusion with or without somatostatin.

After $\mathrm{KCl}$ alone, the urinary excretion of potassium $\left(\mathrm{U}_{\mathrm{K}} \mathrm{V}\right)$ rose from a base line of $56 \pm 15 \mu \mathrm{eq} / \mathrm{min}$ to a maximum of $149 \pm 24 \mu \mathrm{eq} / \mathrm{min}$ at $240 \mathrm{~min}$ (Fig. 7). A similar rise in $U_{K} V$ from $72 \pm 14$ to $184 \pm 8 \mu \mathrm{eq} / \mathrm{min}$ was observed after the combined KCl-somatostatin infusion. Changes in potassium clearance in dogs receiving $\mathrm{KCl}$ alone $(14.3 \pm 3.6$ to $32.7 \pm 5.0 \mathrm{ml} / \mathrm{min})$, likewise, paralleled those in dogs receiving combined $\mathrm{KCl}$-somatostatin infusion (20.6 \pm 3.6 to $37.3 \pm 2.9$ $\mathrm{ml} / \mathrm{min}$ ).

Base-line serum sodium concentration was similar in all three groups ( $\mathrm{KCl}$ alone: $147 \pm 1 \mathrm{meq} / \mathrm{liter} \mathrm{KCl}$

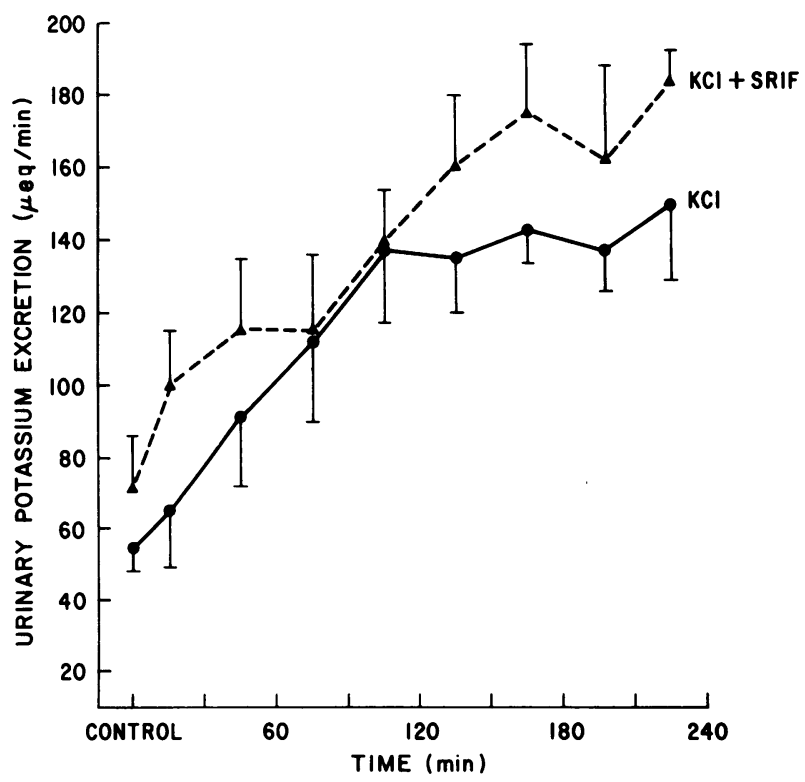

FIGURE 7 The effect of potassium chloride $(\mathrm{KCl})$ infusion alone (O) and $\mathrm{KCl}$ plus somatostatin (SRIF) infusion ( $\Delta$ ) on urinary potassium excretion. 
plus somatostatin: $146 \pm 1 \mathrm{meq} / \mathrm{liter} ; \mathrm{KCl}$ plus somatostatin plus insulin: $145 \pm 1 \mathrm{meq} / \mathrm{liter})$. No change in serum sodium occurred in any of the three experimental groups. Base-line urine sodium excretion (249 $\pm 68 \mu \mathrm{eq} / \mathrm{min})$ and sodium clearance $(1.7 \pm 0.5 \mathrm{ml} / \mathrm{min})$ were unchanged by $\mathrm{KCl}$ alone (Fig. 8). However, addition of somatostatin resulted in a $64 \%$ decline in sodium excretion $\mathrm{U}_{\mathrm{Na}} \mathrm{V}$ at $60-120 \min (P=0.08)$. This decline was followed by a rise in $\mathrm{U}_{\mathrm{Na}} \mathrm{V}$ to levels $50 \%$ above basal at $240 \mathrm{~min}(P<0.05)$. Changes in sodium clearance paralleled those of $\mathrm{U}_{\mathrm{Na}} \mathrm{V}$.

\section{DISCUSSION}

The present findings demonstrate that suppression of basal insulin secretion by somatostatin is associated with an increase in serum potassium concentration in normal subjects and maturity-onset diabetics. Noteworthy is the fact that the rise in serum potassium occurred before a rise in plasma glucose and in the absence of marked hyperglycemia and glucosuria. That this effect of somatostatin is due to insulin deficiency rather than glucagon lack or a direct effect of this agent is suggested by the fact that: (a) somatostatin failed to cause a rise in serum potassium in juvenile-onset diabetics in whom endogenous insulin secretion is markedly reduced; (b) plasma glucagon in juvenile-onset diabetics fell similarly to controls and maturity-onset diabetics (Fig. 1); and (c) the hyperkalemic effect of somato-

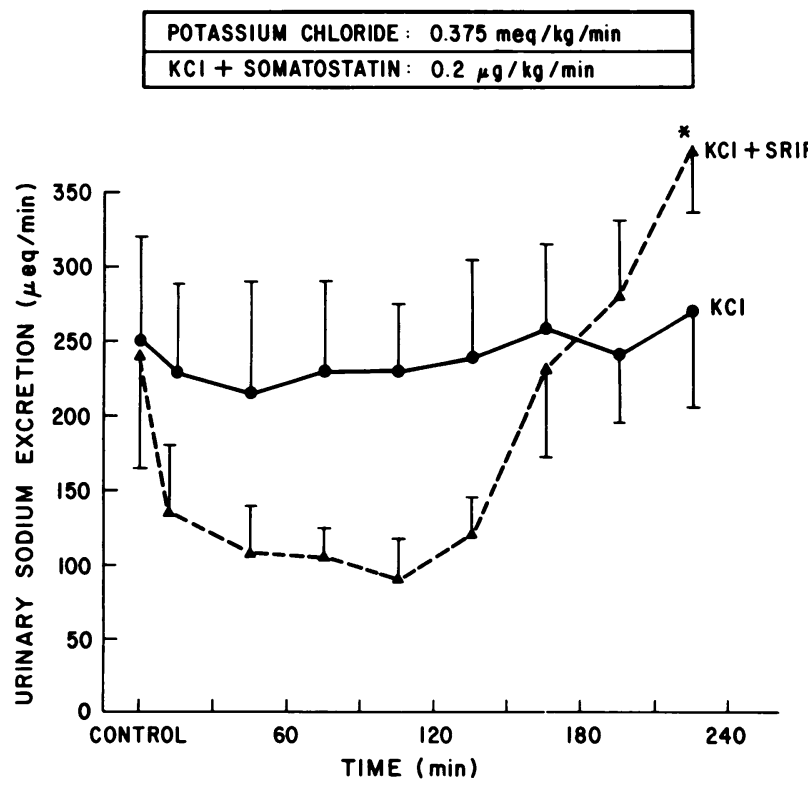

FIGURE 8 The effect of potassium chloride $(\mathrm{KCl})$ infusion alone $(\bullet)$ and $\mathrm{KCl}$ plus somatostatin (SRIF) infusion $(\boldsymbol{\Delta})$ on urinary sodium excretion. An asterisk represents a $P$ value $<0.05$ when compared to basal excretion. statin in normal dogs was overcome by concommitant insulin replacement (Fig. 5). These data thus suggest that basal insulin secretion is an important factor in the maintenance of the fasting plasma potassium concentration within the normal range. When basal insulin secretion is reduced (as with somatostatin administration) a rise in plasma potassium can be expected even in the absence of marked hyperglycemia or volume contraction.

In addition to its effects on endogenous potassium homeostasis, somatostatin resulted in a decrease in "potassium tolerance" when an exogenous potassium load was administered. Previous studies have shown that administration of potassium in doses of 0.9-4.0 $\mathrm{meq} / \mathrm{kg}$ per $\mathrm{h}$ to normal dogs, resulting in an increase in serum potassium of $1 \mathrm{meq} / \mathrm{liter}$ or more, causes a rise in circulating insulin (7-9). This increment in insulin secretion is necessary for the disposal of such doses of potassium as evidenced by decreased potassium tolerance in diabetic animals $(9-11)$. In the present study, a smaller dose of potassium was employed $(0.375 \mathrm{meq} / \mathrm{kg}$ per $\mathrm{h})$, which in the control studies caused an increment in serum potassium of 0.5-0.7 meq/liter, but failed to alter basal insulin levels (Fig. 6). Nevertheless, in the presence of somatostatin-induced insulinopenia, a significant deterioration in potassium tolerance was observed and the rise in serum potassium was twice that observed in the control study. Restoration of basal insulin levels by concommitant infusion of insulin and somatostatin served to normalize the plasma potassium response (Fig. 6). These findings thus indicate a role for basal insulin in the disposal of exogenous potassium as well as in the maintenance of endogenous potassium homeostasis.

With respect to the mechanism whereby basal insulin levels influence potassium homeostasis, altered net renal excretion of potassium cannot account for the rise in serum potassium. During the 4-h potassium chloride infusion, $41 \%(15.5 \mathrm{meq})$ of the administered load could be accounted for by increased potassium excretion in the urine (Fig. 7). When $\mathrm{KCl}$ was administered with somatostatin, a similar fraction $(46 \%)$ of the potassium load was excreted in the urine (Fig. 7), yet the rise in serum potassium concentration more than doubled. In the dogs receiving $\mathrm{KCl}$ alone, if all of the infused potassium that was not excreted via the kidneys $(22.0 \mathrm{meq})$ were retained in the extracellular space (5.0 liters), the serum potassium concentration would be expected to rise by 4.40 meq/liter. The observed increment in the control group was, however, $0.63 \mathrm{meq} / \mathrm{liter}$. Thus, $\sim 86 \%$ of the infused potassium which was not excreted in the urine may be estimated to have been translocated into the intracellular compartment. During somatostatin-induced insulinopenia, the rise in serum potas- 
sium after $\mathrm{KCl}$ administration increased twofold to $1.16 \mathrm{meq} / \mathrm{liter}$. Thus, the percentage of the retained potassium load remaining in the extracellular compartment rose from 14 to $29 \%$.

The effect of insulin on transcellular potassium movement probably occurs in muscle and liver tissue. Andres et al. (5) have shown that a doubling of the insulin concentration perfusing the deep tissues of the forearm markedly enhances potassium uptake without affecting glucose metabolism. A similar uptake of potassium by the liver has been demonstrated by Fenn (6). The present results suggest that basal plasma insulin concentrations influence the net influx of potassium into cells. When the plasma insulin concentration is acutely diminished below basal levels, as with somatostatin, there is a net movement of potassium out of cells or a failure of net uptake when exogenous potassium is administered, resulting in systemic hyperkalemia.

The possible clinical importance of the relationship between basal insulin secretion and potassium homeostasis is underscored by several recent reports of hyperkalemia in diabetic patients in the absence of uremia or acidosis $(25,26)$. In some of the patients hyporeninemic-hypoaldosteronism has been identified as the major factor responsible for hyperkalemia $(27,28)$. Other studies however, have demonstrated that the tendency to hyperkalemia may vary with the severity of the diabetics and may not be manifest despite a reduction in aldosterone secretion (25). Indirect evidence that insulin lack contributes to the development of hyperkalemia in diabetes has been provided by studies demonstrating a hyperkalemic response to glucose infusion which is abolished by prior insulin administration (29). The present findings suggest that insulin deficiency per se may be a contributory factor in the elevation of serum potassium concentration observed in some diabetic patients.

In addition to its action on potassium homeostasis, somatostatin had a biphasic effect on renal sodium excretion. An initial decline in urinary sodium was observed during the first $90 \mathrm{~min}$, following by a progressive rise to values exceeding control levels. This pattern was observed in the healthy humans receiving somatostatin alone (Fig. 4) as well as in the anesthetized dogs receiving somatostatin plus $\mathrm{KCl}$ (Fig. 8).

With respect to the mechanism of these changes in urinary excretion of sodium, the present data are compatible with a direct effect of somatostatin on renal tubular handling of sodium and/or hormonally (insulin and glucagon) mediated changes in renal tubular handling of sodium. Although glucagon has been shown to have a natriuretic effect (14), it is unlikely that hypoglucagonemia was responsible for the initial fall in urine sodium since somatostatin failed to lower glucagon levels in the anesthetized dogs yet a transient decline in urinary sodium excretion was observed (Fig. 8). With regard to the delayed increase in urine sodium loss, this may in part, be a consequence of the sodium chloride administered (50) $\mu \mathrm{eq} / \mathrm{min}$ ) as the vehicle for the somatostatin infusate. On the other hand, since physiologic increments in insulin have an antinatriuretic effect $(12,13)$ the current data raise the possibility that urinary sodium excretion may be influenced by basal levels of insulin in the absence of which urinary sodium excretion may ultimately increase. Regardless of the mechanism involved, the effects of somatostatin on sodium excretion do not appear to be mediated via changes in renal hemodynamics since inulin and PAH clearances were unaffected.

\section{ACKNOWLEDGMENTS}

We thank Andrea Belous, Aida Groszman, and Lauren Brown for their expert technical assistance. We are grateful to Mary Walesky, R. N., Lois Mishiwiec, R.N., and Ralph Jacob for caring for our patients and animals.

This research was supported in part by grants AM13526 and RR125, and by contract AM42221 from the National Institutes of Health and by a grant from Juvenile Diabetes Foundation.

\section{REFERENCES}

1. Brenner, B. M., and R. W. Berliner. 1973. The transport of potassium. Handb. Physiol. Sect. 8 Renal Physiology. 497-519.

2. Himanthongkam, J., R. G. Dluhy, and G. H. Williams. 1974. Potassium-aldosterone-renin interrelationships. $J$. Clin. Endocrinol. Metab. 41: 153-159.

3. Hierholzer, K., M. Wiederholt, H. Holzgreve, G. Giebisch, R. M. Klose, and E. E. Windhager. 1965. Micropuncture study of renal tubular transtubular concentration gradients of sodium and potassium in adrenalectomized rats. Arch. Gesamte. Physiol. Mens. Tiere (Pfluegers). 285: 193-210.

4. Giebisch, G. 1975. Some reflections on the mechanism of renal tubular potassium transport. Yale J. Biol. Med. 48: 315-336.

5. Andres, R., M. A. Baltzan, G. Cader, and K. L. Zierler. 1962. Effect of insulin on carbohydrate metabolism and on potassium in the forearm of man. J. Clin. Invest 41 : $108-115$.

6. Fenn, W. O. 1939. Deposition of potassium and phosphorus with glycogen in rat livers. J. Biol. Chem. 128: 297-309.

7. Hiatt, N., M. B. Davidson, and G. Bonorris. 1972. The effect of potassium chloride infusion on insulin secretion in vivo. Horm. Metab. Res. 4: 64-68.

8. Pettit, G. W., R. L. Vick, and A. M. Swander. 1975. Plasma $\mathrm{K}+$ and insulin: changes during $\mathrm{KCl}$ infusion in normal and nephrectomized dogs. Am. J. Physiol. 228: $107-109$.

9. Santeusanio, F., G. R. Faloona, J. P. Knochel, and R. H. Unger. 1973. Evidence for a role of endogenous insulin 
and glucagon in the regulation of potassium homeostasis. J. Lab. Clin. Med. 81: 809-817.

10. Hiatt, N., L. Morgenstern, M. B. Davidson, G. Bonorris, and A. Miller. 1973. Role of insulin in the transfer of infused potassium to tissue. Horm. Metab. Res. 5: $84-88$.

11. Pettit, G. W., and R. L. Vick. 1974. Contribution of pancreatic insulin to extrarenal potassium homeostasis: a two-compartment model. Am. J. Physiol. 226: 319-324.

12. DeFronzo, R. A., C. R. Cooke, R. Andres, G. R. Faloona, and P. J. Davis. 1975. The effect of insulin on renal handling of sodium, potassium, calcium, and phosphate in man. J. Clin. Invest. 55: 845-855.

13. DeFronzo, R. A., M. Goldberg, and Z. S. Agus. 1976. The effects of glucose and insulin on renal electrolyte transport. J. Clin. Invest. 58: 83-90.

14. Levy, M., and N. L. Starr. 1972. The mechanism of glucagon-induced natriuresis in dogs. Kidney Int. 2: 7684 .

15. Felig, P., J. Wahren, R. Sherwin, and R. Hendler. 1976. Insulin, glucagon, and somatostatin in normal physiology and diabetes mellitus. Diabetes. 25: 1091-1099.

16. Sherwin, R. S., R. Hendler, R. DeFronzo, J. Wahren, and P. Felig. 1977. Glucose homeostasis during prolonged suppression of glucagon and insulin secretion by somatostatin. Proc. Natl. Acad. Sci. U. S. A. 74: $348-352$.

17. Goldring, W., and H. Chasis. 1944. Hypertension and Hypertensive Disease. The Commonwealth Fund, New York. 203 pp.

18. Walser, M., D. G. Davidson, and J. Orloff. 1955. The renal clearance of alkali stable inulin. J. Clin. Invest 34: $1520-1523$

19. Fuhr, J., J. Kaczmarczyk, and C. Kruttgen. 1955. Ein einfache calorimetrische methode zur inulinbestimmung fur neiren-clearance-untersuchungen bei stoffwech- selgesunden und diabetikern. Klin. Worchenschr. 33: 729-730.

20. Hawk, P. B., B. L. Oser, and W. H. Summerson. 1954 Practical Physiological Chemistry. Blakiston Div., McGraw-Hill Book Co., Inc., New York. 13th edition. 506-510.

21. Rosselin, G., R. Assan, R. S. Yalow, and S. A. Berson. 1966. Separation of antibody-bound and unbound peptide hormones labeled with iodine-131 by talcum powder and precipitated silica. Nature (Lond.). 212: 355-357.

22. Wise, J. K., R. Hendler, and P. Felig. 1973. Influence of glucocorticoids on glucagon secretion and plasma amino acid concentrations in man. J. Clin. Invest. 52: 2774-2782.

23. Croxton, F. E. 1959. Elementary Statistics with Application in Medicine and the Biological Sciences. Dover Publications, Inc., New York.

24. Tamborlane, W. V., R. S. Sherwin, R. Hendler, and P. Felig. 1977. Metabolic effects of somatostatin in maturity-onset diabetics. N. Engl. J. Med. In Press.

25. Perez, G. O., L. Lespier, R. Knowles, J. R. Oster, and C. A. Vaamonde. 1977. Potassium homeostasis in chronic diabetes mellitus. Arch. Intern. Med. 137: 852-855.

26. Weidman, P., M. H. Maxwell, P. Rowe, R. Winer, and S. G. Massry. 1975. Role of the renin-angiotensin-aldosterone system in the regulation of plasma potassium in chronic renal disease. Nephron. 15: 35-49.

27. DeFronzo, R. A., R. S. Sherwin, P. Felig, and M. Bia. 1977. Nonuremic diabetic hyperkalemia: possible role of insulin deficiency. Arch. Intern. Med. 137: 842-843.

28. Michelis, M. F., and H. V. Murdaugh. 1975. Selective hypoaldosteronism. Am. J. Med. 59: 1-5.

29. Goldfarb, S., M. Cox, I. Singer, and M. Goldberg. 1976. Acute hyperkalemia induced by hyperglycemia: hormonal mechanisms. Ann. Intern. Med. 84: 426-432. 